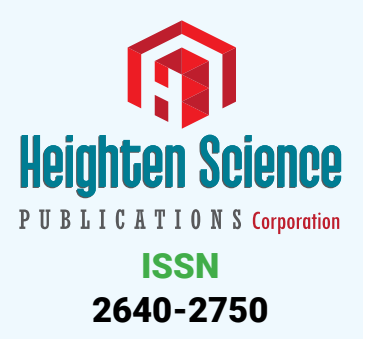

*Address for Correspondence: Dr. Priya Mohan M.D (Pediatrics), Consultant Pediatrician, Ezhil Hospital, Thodiarpet, Chennai, India, Email: priyamohan600@gmail.com

Submitted: 08 June 2017

Approved: 07 July 2017

Published: 10 July 2017

Copyright: @ 2017 Mohan P, et al. This is an open access article distributed under the Creative Commons Attribution License, which permits unrestricted use, distribution, and reproduction in any medium, provided the original work is properly cited

Keywords: Eosinophilic cholangiopathy; Pancreatitis; Cholecystitis; Children

Check for updates

\title{
A rare cause of obstructive jaundice - case report
}

\author{
Priya Mohan ${ }^{1 *}$, Sumathi Bavanandam² and Sunil Kumar KS ${ }^{3}$ \\ ${ }^{1}$ Consultant Pediatrician, Ezhil Hospital, Thodiarpet, Chennai, India \\ ${ }^{2}$ Consultant Pediatric Gastroenterologist, Chennai, India \\ ${ }^{3}$ Senior Consultant Pathologist, Apollo Hospital, Chennai, India
}

\section{ABSTRACT}

Obstructive jaundice in children is not uncommon and has diverse etiologies. We report a rare cause of obstructive jaundice, cholangitis and pancreatic mass in a young boy due to eosinophilic cholangiopathy who responded to oral steroids. Presence of peripheral eosinophilia, elevated serum IgE level, radiological imaging and tissue eosinophilia helped in diagnosis. Eosinophilic cholangiopathy with pancreatitis is a benign treatable cause of obstructive jaundice though it can masquerade as malignancy.

\section{CASE REPORT}

11 years old male child born of non consanguinous parents presented with abdominal pain, fever, jaundice, high coloured urine of 5 days duration. There was no family history of jaundice, allergy. Clinical examination showed scleral icterus, tender hepatomegaly with midline surgical scar. On perusal of his past medical records at seven years of age, from a different hospital he was investigated for generalized lymphadenopathy, hepatosplenomegaly, prolonged fever and distended gall bladder. During the first admission, bone marrow examination was done which was followed by diagnostic laparotomy with cholecystectomy and lymph nodal biopsy. Marrow showed increased eosinophilic precursors and nodal biopsy was inconclusive. Reevaluation of histology of resected gall bladder specimen, showed xanthogranulomatous changes with numerous eosinophils and marked fibrosis suggestive of eosinophilic cholecystitis (Figure 1). As per the history he was not on any drugs. Investigations during this admission showed total count $7300 \times 10^{3} / \mu \mathrm{L}$, polymorphs P $53 \% / \mathrm{L} 34 \% / \mathrm{E}$ $13 \%$. Ultrasonography of abdomen showed hepatomegaly with biliary dilatation, Serum bilirubin $4.5 \mathrm{mg} / \mathrm{dl}$, direct $2.9 \mathrm{mg} / \mathrm{dl}$, SGOT $165 \mathrm{IU} / \mathrm{L}$, SGPT $125 \mathrm{IU} / \mathrm{L}$, SAP $2875 \mathrm{IU} / \mathrm{L}, \mathrm{GGT} 445 \mathrm{IU} / \mathrm{L}$, serum albumin $3.9 \mathrm{gm} / \mathrm{dl}$, amylase $48 \mathrm{IU} / \mathrm{l}$, lipase $26 \mathrm{IU} / \mathrm{l}$. Blood sugar, renal function tests were within normal limits. Serum IgE level above 1000 IU, absolute eosinophil count 920 cells/cumm. A diagnosis of Eosinophilic Cholangiopathy was considered. Autoimmune markers, screening for viral hepatitis, retroviral screening were negative. Due to financial constrains IgG subgroup was not done. MRI abdomen with MRCP showed biliary dilatation with pancreatic head mass (Figure 2). Based on the above clinical picture and earlier biopsy findings from gall bladder on reevaluation, diagnosis of Eosinophilic Cholangiopathy with pancreatitis was considered and hence repeat biopsy from pancreas was not done. He was started on oral prednisolone $1 \mathrm{mg} / \mathrm{kg}$ for 6 months till now. As there are literature evidence in support of medical management, ERCP was not contemplated He responded well to treatment with decline in liver function tests, serum IgE level to $124 \mathrm{IU}$, eosinophil count to $7 \%$ and resolution of symptoms. The boy is on regular follow up. 


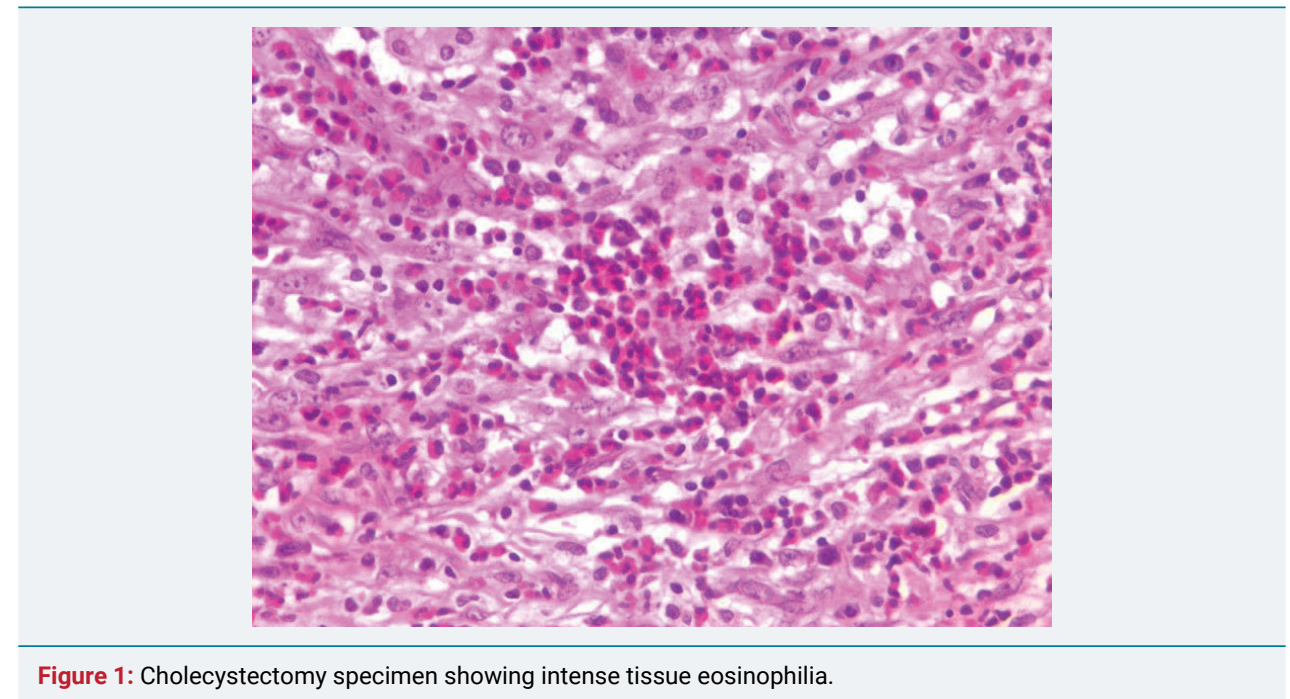

Figure 1: Cholecystectomy specimen showing intense tissue eosinophilia

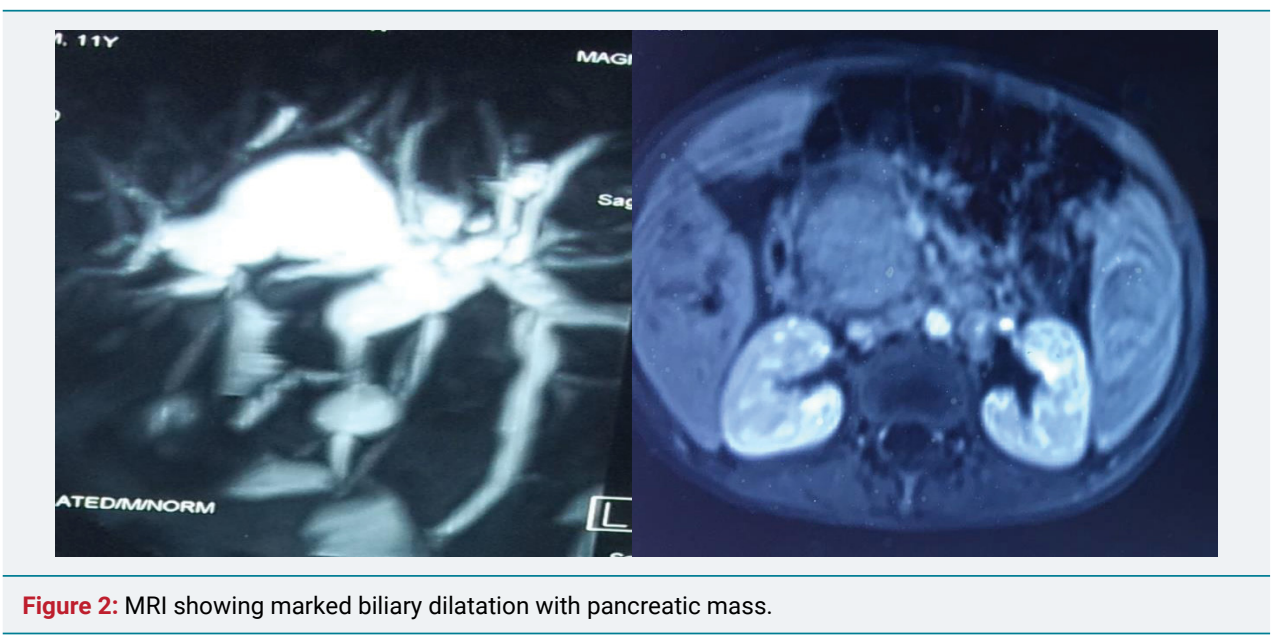

\section{DISCUSSION}

Eosinophilic cholangiopathy is a rare benign disorder of the biliary system presenting as eosinophilic cholecystitis, eosinophilic cholangitis, eosinophilic pancreatitis. It is characterised by diffuse eosinophilic infiltration of the gallbladder wall, bile ducts, and pancreas respectively. Clinically children can present with benign biliary obstruction, with or without pancreatic mass lesion often being misdiagnosed as malignancy. This entity was first described by Leegard in 1980 and since then cases are being reported worldwide. Though the exact cause is not known, it has been reported with cholelithiasis, parasitic infestation, hypereosinophilic syndromes and allergic disorders [1,2].

Eosinophilic cholecystitis cannot be clinically distinguished from other forms of cholecystitis and the confirmation is often made by tissue histology [3]. Our patient presented with acalculous cholecystitis presenting as pyrexia of unknown origin requiring laparotomy with cholecystectomy. Probably he had progression of disease, presenting as obstructive jaundice due to cholangiopathy now. Though peripheral eosinophilia is present in most patients, bone marrow biopsy showing eosinophilic infiltration is known to occur $[4,5]$.

Diagnostic criteria as proposed by Matsumoto et al. defines (1) wall thickening or stenosis of the biliary system; (2) histopathological findings of eosinophilic infiltration; and (3) reversibility of biliary abnormalities without treatment or following steroid treatment [6]. 
There are few case reports with pancreatic involvement mistaken for malignancy [7]. Multisystem involvement of liver, pleural, peritoneum and gastrointestinal tract, ureters are also reported [8], Treatment options are many including ERCP stent placement, hepaticojejunostomy and oral steroids. This case is being reported for its rarity. Although the role of steroids and hydroxyurea remains unclear, there are several cases of successful treatment with oral corticosteroids alone [9].

\section{REFERENCES}

1. Kim YH. Eosinophilic cholecystitis in association with clonorchis sinesis infestation in the common bile duct. Clin Radiol. 1999; 54: 552-554. Ref.: https://goo.gl/N6AGV4

2. Raptou G, Pliakos I, Hytiroglou P, Papavramidis S, Karkavelas G. Severe eosinophilic cholangitis with parenchymal destruction of the left hepatic lobe due to hydatid disease. Pathol Int. 2009; 59: 395-398. Ref.: https://goo.gl/Y2Q1oX

3. Nashed C, Sakpal SV, Susharina V. Chamberlain RS. Eosinophilic cholangitis and cholangiopathy: a sheep in wolves clothing. HPB Surg. 2010; 2010: 906496. Ref.: https://goo.gl/25qQ2v

4. Goode EC, Simpson BW, Rushbrook SM. A rare cause of cholangiopathy. Gastroenterology. 2013; 144: 14-15. Ref.: https://goo.gl/RQGXFp

5. Chen WH, Yu CC, Wu CC, Jan YJ. Eosinophilic cholangitis with obstructive jaundice mimicking bile duct carcinoma. J Hepatobiliary Pancreat Surg. 2009; 16: 242-245. Ref.: https://goo.gl/FcwtK8

6. Matsumoto N, Yokoyama K, Nakai K, Yamamoto T, Otani T, et al. A case of eosinophilic cholangitis: imaging findings of contrast-enhanced ultrasonography, cholangioscopy, and intraductal ultrasonography. World J Gastroenterol. 2007; 13: 1995-1997. Ref.: https://goo.gl/iQA1Pq

7. Cay A, Imamoglu M, Cobanoglu U. Eosinophilic pancreatitis mimicking pancreatic neoplasia Can J Gastroenterol 2006; 20: 361-364. Ref.: https://goo.gl/uPVXxY

8. Vauthey JN, Loyer E, Chokshi P, Lahoti S. Case 57: eosinophilic cholangiopathy. Radiology. 2003; 227: 107-112. Ref.: https://goo.gl/SbmVer

9. Duseja A, Nada R, Dhiman RK, Chawla YK, Kalra N, et al. Eosinophilic cholangiopathy-a case report. Dig Dis Sci. 2005; 50: 1422-1425. Ref.: https://goo.gl/Pqp264 